\title{
Ecotoxicological evaluation of electrochemical oxidation for the treatment of sanitary landfill leachates
}

\author{
Annabel Fernandes ${ }^{1}$ (D) - Manuel Ramiro Pastorinho ${ }^{2,3} \cdot$ Ana Catarina Sousa ${ }^{2,3,4,5} \cdot$ Wilson Silva $^{1,2} \cdot$ Rodrigo Silva $^{1}$. \\ Maria João Nunes ${ }^{1} \cdot$ Ana Sofia Rodrigues ${ }^{1} \cdot$ Maria José Pacheco $^{1} \cdot$ Lurdes Ciríaco $^{1} \cdot$ Ana Lopes $^{1}$
}

Received: 29 March 2018 / Accepted: 25 June 2018

(C) Springer-Verlag GmbH Germany, part of Springer Nature 2018

\begin{abstract}
In this study, the efficiency of electrochemical oxidation to treat a sanitary landfill leachate was evaluated by the reduction in physico-chemical parameters and in ecotoxicity. The acute toxicity of the sanitary landfill leachates, before and after treatment, was assessed with the model organism Daphnia magna. Electrochemical oxidation treatment was effective in the removal of organic load and ammonium nitrogen and in the reduction of metal ions concentrations. Furthermore, a reduction of 2.5 -fold in the acute toxicity towards D. magna after $36 \mathrm{~h}$ of treatment was noticed. Nevertheless, the toxicity of the treated leachate is still very high, and further treatments are necessary in order to obtain a non-toxic effluent to this aquatic organism. Toxicity results were also compared with others described in the literature for different leachate treatments and test organisms.
\end{abstract}

Keywords Sanitary landfill leachate $\cdot$ Electrochemical oxidation $\cdot$ Boron-doped diamond anode $\cdot$ Daphnia magna $\cdot$ Acute toxicity

\section{Introduction}

Sanitary landfill leachates (SLL), due to its composition, are an important environmental problem with known toxic effects towards wildlife and human health (Öman and Junestedt 2008; Eggen et al. 2010). The efficient treatment

Responsible editor: Philippe Garrigues

Annabel Fernandes

annabelf@ubi.pt

$\triangle$ Ana Catarina Sousa

anasousa@fcsaude.ubi.pt

1 FibEnTech/UBI and Department of Chemistry, Universidade da Beira Interior, 6201-001 Covilhã, Portugal

2 Health Sciences Research Centre (CICS), Universidade da Beira Interior, 6200-506 Covilhã, Portugal

3 NuESA-Health and Environment Study Unit, Faculty of Health Sciences, Universidade da Beira Interior, 6200-506 Covilhã, Portugal

4 CNRS LabEx DRIIHM; CNRS-INEE-ECCOREV (Unité FR3098); OHMi Estarreja-OHM Bassin Minier de Provence; Europôle méditerranéen de L'Arbois, Bât du CEREGE-BP 80, 13545 Aix en Provence, Cedex 4, France

5 CICECO and Department of Chemistry, Universidade de Aveiro, 3810-193 Aveiro, Portugal of these effluents to effectively eliminate combined toxicity is one of the greatest challenges in waste management. Conventional biological processes, the most cost-effective processes for wastewater treatment, have shown to be insufficient for the treatment of SLL. Therefore, the application of less conventional technologies and integration of different treatment processes to deal with such effluents is, nowadays, an important topic of research.

Among the emerging technologies developed for landfill leachates treatment, electrochemical oxidation (EO) has received great attention due to its effectiveness and ease in operation (Martínez-Huitle and Ferro 2006; Rao and Venkatarangaiah 2014; Martínez-Huitle et al. 2015). There are several studies describing the application of EO for SLL treatment with promising results, being borondoped diamond (BDD) the most intensively studied anode material (Anglada et al. 2009; Sirés et al. 2014; Fernandes et al. 2015). Anglada et al. (2010) reported chemical oxygen demand (COD) and ammonia nitrogen removals of $100 \%$ when applying EO for SLL treatment, using BDD anodes. In addition, Panizza and Martinez-Huitle (2013) achieved similar results using the same anode material. Fernandes et al. (2014) described the increase in the biodegradability index and the removal of metals from landfill leachates, due to its deposition on the cathode surface, during EO treatment. 
EO presents very good results in the elimination of organic load and ammonia, being the later identified as a major toxic constituent present in landfill leachates (Thomas et al. 2009). However, the influence of the EO treatment in the toxicity of the leachates is not well known, since the removal of contaminants might not always correspond to a quantitative reduction of the toxic effects. Due to the complex nature of the waste and to the processes taking place within landfills, physicochemical and biological parameters, such as COD, biochemical oxygen demand $\left(\mathrm{BOD}_{5}\right)$, total organic carbon (TOC), and ammonia, the most commonly used to evaluate effluent quality after treatment, are not sufficient to evaluate the toxicity to organisms, caused by these effluents (Ma et al. 2005). Thus, to better characterize the toxicity removal potential of a given treatment, ecotoxicological tests with aquatic organisms should be performed (Ma et al. 2005).

Some authors already used bioassays with aquatic organisms to evaluate the toxicity profile of electrochemical oxidation technologies for effluent treatment (Ghosh et al. 2017). Anglada et al. (2011) assessed the acute ecotoxicity of a landfill leachate, before and after an EO treatment with a BDD anode, using the luminescent marine bacteria Vibrio fischeri, and the authors have found a decrease in the toxicity. However, data on the efficiency in toxicity removal during electrochemical oxidation of SLL using freshwater invertebrates is limited. Hence, this work aims to fill this gap by evaluating the ecotoxicity of the treated leachates towards Daphnia magna. This organism is a small freshwater crustacean that feeds on green algae, being at the bottom of the food web and thus plays a key role in the ecosystems' health. Due to its short lifespan, easiness of rearing, and reproduction by parthenogenesis, it is widely used as a model species in ecotoxicological tests being recommended by the major international organizations, namely American Society for Testing and Materials (ASTM), Organisation for Economic Cooperation and Development (OECD), and International Organization for Standardization (ISO).

The aims of this work were to assess the toxicity of sanitary landfill leachates treated by EO, using a BDD anode, and to evaluate the efficacy of the treatment method in the simultaneous reduction of organic load, metal ions, and toxicity towards the model species Daphnia magna (Straus, 1820).

\section{Materials and methods}

\section{Sample characterization}

The sanitary landfill leachate used in this study was collected from an intermunicipal sanitary landfill facility. This site, which serves a population of over 368,000 inhabitants in 19 municipalities, has an onsite facility that comprises two reverse osmosis systems followed by a stripping column and is capable of treating up to $175 \mathrm{~m}^{3}$ of leachate daily. The leachate sample was collected from the homogenization tank, before any kind of treatment, and its main characteristics are presented in Table 1.

\section{Electrodegradation experiments}

The EO experiments were conducted in batch mode, with stirring, using $300 \mathrm{~mL}$ of leachate at natural conditions. A commercial $\mathrm{Si} / \mathrm{BDD}$ anode $\left(20 \mathrm{~cm}^{2}\right)$, purchased from Adamant Technologies, and a stainless-steel cathode $\left(20 \mathrm{~cm}^{2}\right)$ were utilized as electrodes, being the inter-gap $0.5 \mathrm{~cm}$. Electrolyzes were performed at an applied current density of $700 \mathrm{~A} \mathrm{~m}^{-2}$, using a GW, Lab DC, model GPS3030D (0-30 V, 0-3 A) as power supply. Assays had durations of $4,8,12,16,20,24,28,32$, and $36 \mathrm{~h}$, and in all trials, samples were collected every $4 \mathrm{~h}$, in order to perform analytical determinations and monitor the experiments.

All the EO assays were performed at least in duplicate. The values presented for the parameters used to follow the assays are mean values.

\section{Toxicological assays}

Test organism—Daphnia magna (Straus, 1820)

The freshwater crustacean D. magna cultured in the laboratory, under standardized conditions, was used to perform the

Table 1 Characterization of the sanitary landfill leachate sample used in the experiments

\begin{tabular}{|c|c|}
\hline Parameter & Mean value $( \pm \mathrm{SD})$ \\
\hline $\mathrm{COD} / \mathrm{g} \mathrm{L}^{-1}$ & $11.9 \pm 0.7$ \\
\hline $\mathrm{BOD}_{5} / \mathrm{g} \mathrm{L}^{-1}$ & $1.62 \pm 0.07$ \\
\hline $\mathrm{BOD}_{5} / \mathrm{COD}$ & 0.14 \\
\hline $\mathrm{TC} / \mathrm{g} \mathrm{L}^{-1}$ & $9.0 \pm 0.2$ \\
\hline $\mathrm{TOC} / \mathrm{g} \mathrm{L}^{-1}$ & $4.9 \pm 0.1$ \\
\hline $\mathrm{IC} / \mathrm{g} \mathrm{L}^{-1}$ & $4.1 \pm 0.1$ \\
\hline $\mathrm{TN} / \mathrm{g} \mathrm{L}^{-1}$ & $4.7 \pm 0.3$ \\
\hline $\mathrm{TKN} / \mathrm{g} \mathrm{L}^{-1}$ & $4.4 \pm 0.2$ \\
\hline $\mathrm{N}-\mathrm{NH}_{3} / \mathrm{g} \mathrm{L}^{-1}$ & $3.9 \pm 0.2$ \\
\hline Chloride/g L ${ }^{-1}$ & $7.2 \pm 0.3$ \\
\hline Nickel/mg L ${ }^{-1}$ & $1.32 \pm 0.06$ \\
\hline Zinc/mg L ${ }^{-1}$ & $0.65 \pm 0.01$ \\
\hline Lead/mg L ${ }^{-1}$ & $0.30 \pm 0.02$ \\
\hline Cadmium $/ \mathrm{mg} \mathrm{L}^{-1}$ & $0.069 \pm 0.003$ \\
\hline Acute toxicity $\left(\mathrm{EC}_{50}(48 \mathrm{~h}) / \mathrm{TU}\right)$ & $1.01 \% / 98.6$ \\
\hline $\mathrm{pH}$ & $8.4 \pm 0.1$ \\
\hline Conductivity $/ \mathrm{mS} \mathrm{cm}^{-1}$ & $48.3 \pm 0.6$ \\
\hline
\end{tabular}

$S D$ standard deviation, $T U$ toxic units $\left(\mathrm{TU}=100 / \mathrm{EC}_{50}, 10<\mathrm{TU}<100\right.$ : very toxic (Pablos et al. 2011)) 
toxicological assays. In short, adult females of D. magna (30 individuals per 1-L jar) were maintained in ASTM (American Society of Testing Materials) hard water under controlled temperature and light conditions $\left(T=20 \pm 1{ }^{\circ} \mathrm{C}\right.$; photoperiod: 12:12 h light/dark). The daphnids were fed daily with a suspension of the green algae Raphidocelis subcapitata $(3.0 \times$ $10^{5}$ cells $\mathrm{mL}^{-1}$ ), and the culture media (supplemented with seaweed extract) was changed three times per week. Prior to the performance of the test, adult daphnids were isolated and maintained in 100-mL glass beakers under the same standard conditions. The 3 rd to the 5 th broods were used to perform toxicity tests, whereas the animals from the 6 th brood were used to start new cultures.

\section{D. magna test validation}

OECD Guideline 202 (2004) recommends a test with a reference substance (such as potassium dichromate), preferably, every month and at least twice a year in order to assess the sensitivity of the organisms. Hence, prior to the tests with the real samples, a 24-h acute toxicity test with $\mathrm{K}_{2} \mathrm{Cr}_{2} \mathrm{O}_{7}$ was performed. Six different concentrations of $\mathrm{K}_{2} \mathrm{Cr}_{2} \mathrm{O}_{7}$ were prepared in ASTM water and tested in quadruplicate alongside a control (ASTM water). For each replicate, 5 neonates with less than $24 \mathrm{~h}$ were exposed to the test solution during $24 \mathrm{~h}$. After this exposure period, the number of immobilized daphnids was registered and the concentration responsible for $50 \%$ of immobilization $\left(\mathrm{EC}_{50}\right)$ calculated using the Sigmaplot software package (v12.5).

\section{Acute toxicity tests}

The acute toxicity tests were performed in neonates with less than $24 \mathrm{~h}$ from the $3 \mathrm{rd}$ to the 5 th brood in accordance with the OECD Guideline 202 (2004). Five replicates, with five neonates each, were tested on a set of dilutions $(0.5,1,1.5,2,2.5$, and $3 \%$ ) of each treatment with different duration $(4,8,12,16$, $20,24,28,32,36 \mathrm{~h}$ ) and for the untreated effluent (raw sample, $t=0 \mathrm{~h}$ ). Immobilized daphnids were registered after 24 and $48 \mathrm{~h}$ of exposure and $\mathrm{EC}_{50}$ calculated. All the tests were performed within 1 week of the EO treatment and the treated samples were maintained under dark conditions at $4{ }^{\circ} \mathrm{C}$.

\section{Physicochemical determinations}

The samples collected before, during, and after the electrodegradation assays were analyzed, according to the procedures described in the Standard Methods (Eaton et al. 2005), for the following parameters: $\mathrm{COD}, \mathrm{BOD}_{5}$, TOC, total carbon (TC), inorganic carbon (IC), total nitrogen (TN), total Kjeldahl nitrogen (TKN), and ammonia nitrogen $\left(\mathrm{N}-\mathrm{NH}_{3}\right)$.

COD determinations were made using the closed reflux titrimetric method adapted to samples containing high concentrations of chloride (Freire and Sant'Anna 1998; Eaton et al. 2005). The digestion of the samples occurred in strongly acid solution with a known excess of potassium dichromate, with addition of a silver compound as catalyst, to promote the oxidation of resistant organic compounds, and mercury sulfate, to reduce interferences from the oxidation of chloride ions. The sample closed reflux digestion was performed in a thermoreactor Merck Spectroquant TR 420, during $2 \mathrm{~h}$ at $150{ }^{\circ} \mathrm{C}$. After digestion, the remaining unreduced dichromate was titrated with ferrous ammonium sulfate, using ferroine as indicator, to determine the amount of dichromate consumed, which is equivalent to the amount of oxygen required to oxidize the organic matter.

The $\mathrm{BOD}_{5}$ was evaluated by the respirometric method, which provided the direct measurement of the oxygen consumed by microorganisms from an air-enriched environment, after 5 days of incubation, in a closed vessel, under conditions of constant temperature $\left(20 \pm 1^{\circ} \mathrm{C}\right)$ and stirring. Manometric respirometers that relate oxygen uptake with the change in pressure caused by oxygen consumption at constant volume were used. The assays were performed in a WTW Oxitop IS 12 Inductive Stirring System, in a WTW TS 606-G/2-i Thermostat Cabinet, using lyophilized biomass PolySeed, commercially available.

A Shimadzu TOC-VCPH analyzer combined with a TNM1 unit was used to measure TC, TOC, IC, and TN. TKN and $\mathrm{N}-\mathrm{NH}_{3}$ were determined according to standard procedures using a Kjeldatherm block-digestion-system and a Vapodest 20-s distillation system, both from Gerhardt.

Nitrate, nitrite, chloride, chlorate, and perchlorate ions concentrations were determined by ion chromatography, using a Shimadzu's Prominance LC-20A system with a Shimadzu CDD 10Avp conductivity detector, equipped with an IC I524A Shodex $(4.6 \mathrm{~mm} \mathrm{ID} \times 100 \mathrm{~mm})$ anion column. The mobile phase was an aqueous solution of $2.5 \mathrm{mM}$ of phthalic acid, at $\mathrm{pH} 4$, with a flow rate of $1.5 \mathrm{~mL} \mathrm{~min}^{-1}$. Column temperature was $40{ }^{\circ} \mathrm{C}$.

Nickel, zinc, lead, and cadmium concentrations were determined by flame atomic absorption spectrometry using a Perkin Elmer AAnalyst 800 spectrometer. The sample preparation followed a procedure adapted from Standard Methods (Eaton et al. 2005) and Sabejeje et al. (2014) that includes an $\mathrm{HNO}_{3} / \mathrm{HCl}$ acid digestion. Thus, $5 \mathrm{~mL}$ of $\mathrm{HNO}_{3}$ was added to $50 \mathrm{~mL}$ of leachate sample and the mixture was heated to boiling and evaporated to a final volume of $20 \mathrm{~mL}$. After cooling, $5 \mathrm{~mL}$ of $\mathrm{HNO}_{3}$ was added to the remaining $20 \mathrm{~mL}$ of the mixture sample, the beaker was covered and, in the hot plate, temperature was increased until a gentle reflux occurred. When a clear solution was observed, indicating complete digestion of the sample, the mixture was removed from the hot plate. After cooling, $2 \mathrm{~mL}$ of $\mathrm{HNO}_{3}$ was added to the mixture sample and heated until complete dissolution of the 
precipitate. After cooling, $10 \mathrm{~mL}$ of a $\mathrm{HCl}$ solution $(5 \mathrm{~mL}$ of $\mathrm{HCl} 37 \%+5 \mathrm{~mL}$ of ultrapure water) was added to the mixture sample. The beaker was covered and returned to the hot plate where it stayed in a gentle reflux during 30 min. After cooling, the sample was filtered, transferred to a $50-\mathrm{mL}$ plastic volumetric flask, and diluted with ultrapure water, obtained with Milli-Q® equipment. Each sample was prepared and analyzed three times.

The $\mathrm{pH}$ was measured using a HANNA $\mathrm{pH}$ meter (HI 931400). The conductivity was determined using a Mettler Toledo conductivity meter (SevenEasy S30K).

\section{Results and discussion}

Figure $1 \mathrm{a}, \mathrm{b}$ presents, respectively, COD and carbon decays along EO treatment. Until 16-h treatment, a regular linear decay in COD and carbon content is observed, pointing to a high mineralization degree of the easily oxidized species present in the sample. This regular linear decay, typical of an electrochemical reaction controlled by electrical current, was expected and can be explained by the high COD values presented by the landfill leachate in the first hours of the assay, which are higher than critical COD, according to medium mass transfer coefficients presented in literature for leachate samples (Anglada et al. 2011; Fernandes et al. 2012). For longer treatment times, pollutant's concentration significantly decreased and a different decay behavior is observed, since the electrochemical reaction is mainly controlled by the diffusion of the species undergoing degradation towards the electrode surface. The treatment time was prolonged until the COD of the treated solution was below the legal Portuguese discharge limit $\left(150 \mathrm{mg} \mathrm{L}^{-1}\right)$. Thus, after 36-h treatment, COD, TOC, and IC values were, respectively, 54, 33, and $230 \mathrm{mg} \mathrm{L}^{-1}$,

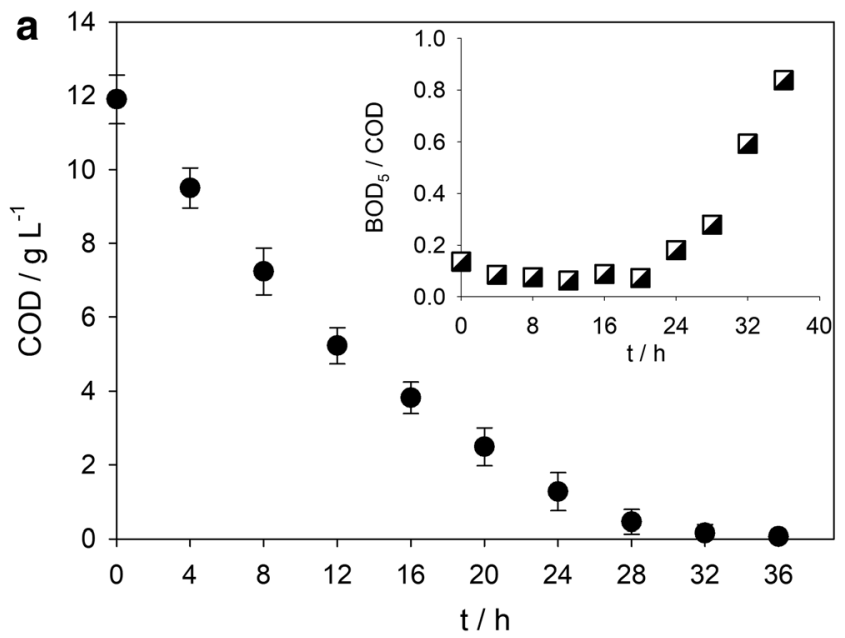

Fig. 1 a COD decay and (inset) biodegradability index evolution. b TC, TOC, and IC decays along EO treatment performed at the following conditions: volume of landfill leachate $-0.3 \mathrm{~L}$; anode - BDD plate with being most of the carbon content in the form of inorganic carbon.

From Fig.1b, it can be seen that, despite similar TOC and IC initial concentrations, TOC removal rate is slightly higher than IC removal rate, which points to a low net formation rate of inorganic forms of carbon that remain in solution, such as carbonates. This is corroborated by the high decrease in TC that points to a high mineralization degree, with formation of carbon volatile compounds, such as $\mathrm{CO}_{2}$.

Figure 1a (inset) contains the values of the biodegradability index $\left(\mathrm{BOD}_{5} / \mathrm{COD}\right)$ obtained. There are no significant differences in the biodegradability index in the first 20-h treatment. However, after that time, the biodegradability index increased exponentially, reaching the value of 0.84 after 36 -h treatment. The small variation observed up to 20 -h treatment can be explained by the high pollutants' concentration in the first hours of the assay and by the formation of nonbiodegradable intermediates, such as organochloride compounds. By continuing the oxidation process, more oxidized intermediates are formed, such as short-chain carboxylic acids that are easily biodegradable and are known to be present in the final stage of EO treatment (Panizza and Cerisola 2009; Brillas and Martínez-Huitle 2015).

Regarding nitrogen forms evolution, presented in Fig. 2a, a regular linear decay for ammonia nitrogen is observed, being this nitrogen form inexistent at $36-\mathrm{h}$ assay. According to literature, considering the high chloride concentration present in the leachate, ammonia nitrogen removal should occur mainly through indirect oxidation, originating nitrogen gas and nitrate (Pérez et al. 2012). As can be seen in Table 1, about $83 \%$ of the initial total nitrogen was in the form of ammonia nitrogen and the remainder in the form of organic nitrogen. During the 36-h EO treatment, $80 \%$ of total nitrogen was removed, and, at the end of the treatment, all nitrogen present in solution was

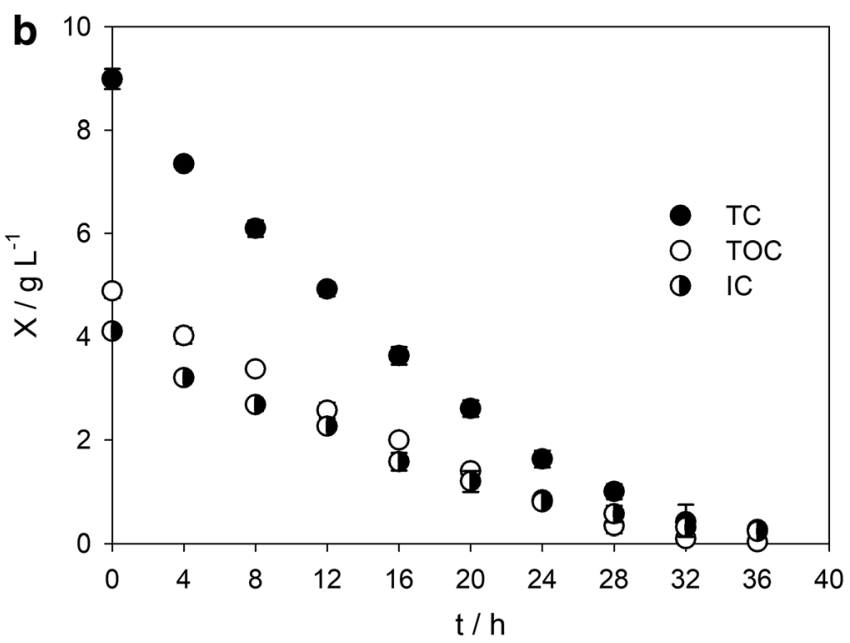

$20 \mathrm{~cm}^{2}$; cathode - stainless steel plate with $20 \mathrm{~cm}^{2}$; distance between electrodes $-0.5 \mathrm{~cm}$; applied current density $-700 \mathrm{~A} \mathrm{~m}^{-2}$; natural $\mathrm{pH}$ 


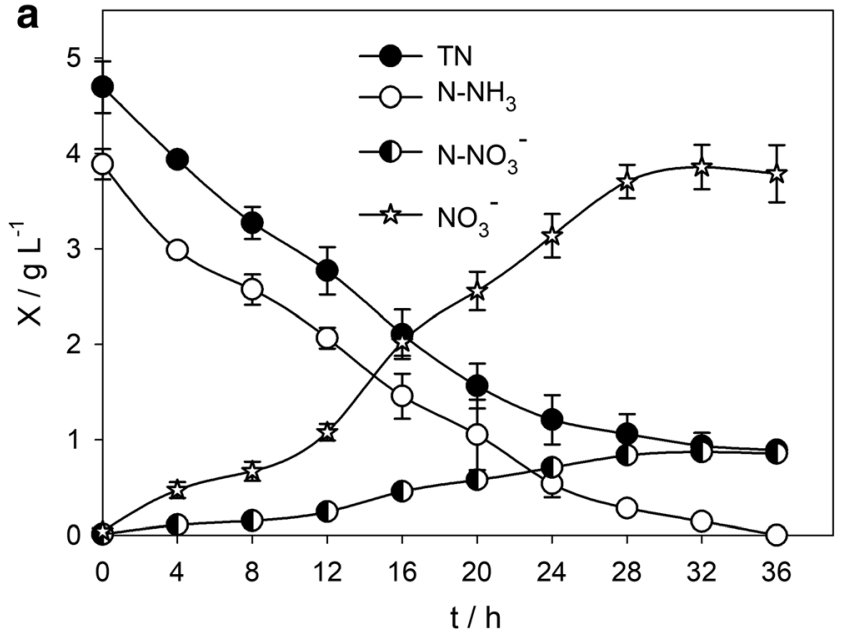

Fig. 2 a $\mathrm{TN}, \mathrm{N}-\mathrm{NH}_{3}, \mathrm{NO}_{3}{ }^{-}$(nitrate concentration), and $\mathrm{N}^{-\mathrm{NO}_{3}}{ }^{-}$ (nitrogen concentration in nitrate form). b Chloride, chlorate, and perchlorate evolution along EO treatment performed at the following

in the form of nitrate, with a concentration of $3.8 \mathrm{~g} \mathrm{~L}^{-1}$. No nitrite ions were detected during the $\mathrm{EO}$ treatment. Thus, it can be assumed that ammonia nitrogen was converted into nitrate and oxidation of organic matter yielded ammonia, which was then oxidized to nitrate. This assumption was reported in a previous study (Anglada et al. 2011). In addition, attending to the amount of nitrate formed during the assays, it can be concluded that nitrogen removal preferentially took place by the formation of nitrogen gas, since the amount of $\mathrm{N}^{-\mathrm{NO}_{3}}{ }^{-}$ produced is quite inferior to the TN removed. This observation is in accordance with literature, which states that at high chloride concentration, the formation of nitrogen gas is favored (Pérez et al. 2012).

When chlorine species are analyzed (Fig. 2b), it can be seen that chloride concentration linearly decreases during EO treatment, being inexistent after $28 \mathrm{~h}$, which is due to the formation of other chlorine species. Chloramines, considered as very toxic substances, are, according to literature, produced during the first hours of EO treatment, due to the presence of ammonia and free chlorine in solution, being eliminated at the end of the assay (Pérez et al. 2012). Despite chloramines were not monitored in the present work, their presence in solution can be excluded after 36-h treatment, since all nitrogen was in the form of nitrate. Other undesirable chloride oxidation by-products, referred in literature, are chlorate and perchlorate (Pérez et al. 2012), monitored in the present work, being the results presented in Fig. 2b. Chlorate formation occurred during the EO treatment; it increases with time, achieving a maximum at 24-h assay, and then decreases, being completely eliminated at 32-h assay. Regarding perchlorate concentration, it was observed that it increased with time, at higher formation rate than chlorate, achieving a plateau after 24-h assay, meaning that it is a stable end-product of the chloride oxidation in the presence of BDD anodes, as previously reported (Pérez et al.

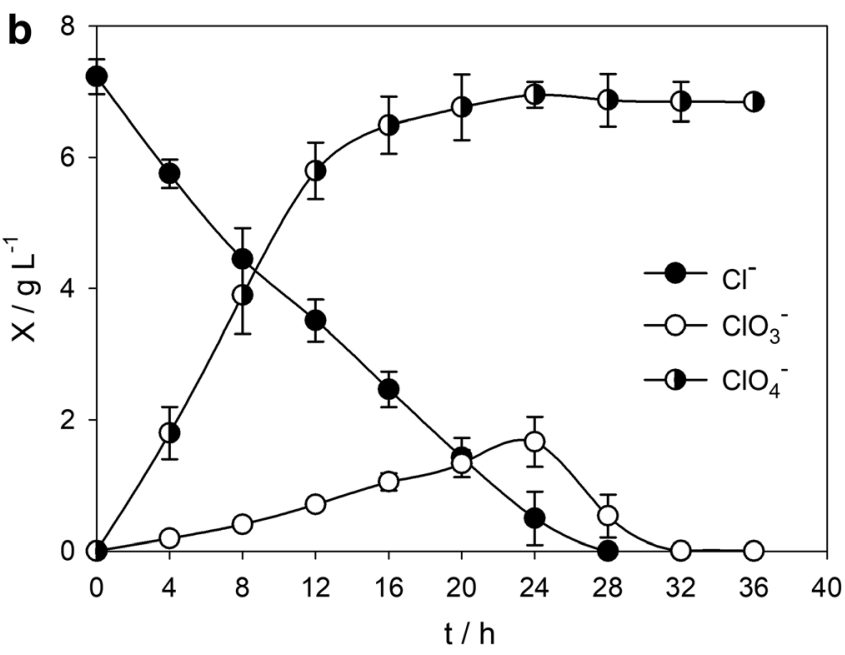

conditions: volume of landfill leachate $-0.3 \mathrm{~L}$; anode $-\mathrm{BDD}$ plate with $20 \mathrm{~cm}^{2}$; cathode - stainless steel plate with $20 \mathrm{~cm}^{2}$; distance between electrodes $-0.5 \mathrm{~cm}$; applied current density $-700 \mathrm{~A} \mathrm{~m}^{-2}$; natural $\mathrm{pH}$

2012). The perchlorate concentration at $36 \mathrm{~h}$ of EO treatment was approximately $7 \mathrm{~g} \mathrm{~L}^{-1}$.

Since landfill leachates can contain metals in its composition (Öman and Junestedt 2008; Eggen et al. 2010), some of them with toxic effects, the concentration of the most relevant heavy metals usually found in leachates was determined before and during the EO treatment. Nickel and zinc were chosen from the group of essential metals, and lead and cadmium were selected from non-essential metals. Figure 3 presents the heavy metal decay along EO treatment. For the essential metals (Fig. 3a), which exist in higher concentrations in the leachate, a marked decrease in its concentration can be observed, due to cathodic reduction. For the toxic metals lead and cadmium (Fig. $3 b)$, despite the low concentrations found in the leachate, a decrease in its concentration was also attained, being this decrease by one order of magnitude for lead.

Regarding ecotoxicity tests, they were validated by accessing the sensitivity of the daphnids using the reference substance potassium dichromate. The $\mathrm{EC}_{50}$ value obtained $\left(0.873 \mathrm{mg} \mathrm{L}^{-1}\right)$ is within the recommended range $(0.6-$ $\left.2.1 \mathrm{mg} \mathrm{L}^{-1}\right)(\mathrm{OECD} / \mathrm{OCDE} 2004)$, and the mortality in the control was always lower than $10 \%$. After verifying the sensitivity of the organisms, a series of range finding tests were performed, to access the leachate concentrations to be used in the subsequent toxicity tests. It was concluded that leachate dilutions above 3\% (corresponding to 3\% leachate, 97\% ASTM) were responsible for $100 \%$ mortality, and thus, concentrations below this value $(0.5,1,1.5,2,2.5$, and $3 \%)$ were tested. Table 2 and Fig. 4 depict the obtained results. After $48 \mathrm{~h}$ of exposure, the initial non-treated leachate (corresponding to $0 \mathrm{~h}$ ) is toxic towards Daphnia with an $\mathrm{EC}_{50}$ close to $1 \%$, which according to the toxicity classification based on toxic units (TUs) reported by Pablos et al. (2011) 


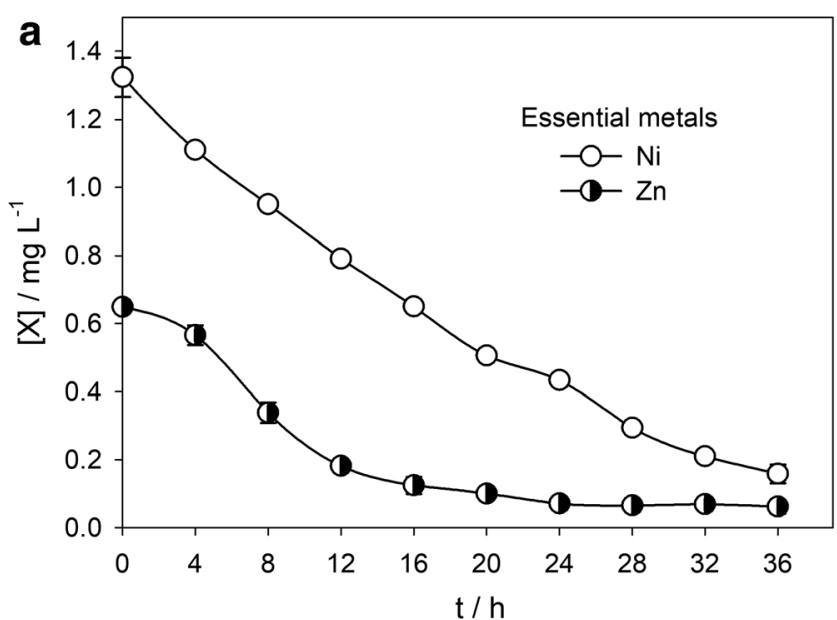

Fig. 3 a $\mathrm{Ni}$ and $\mathrm{Zn}$ decays; $\mathbf{b} \mathrm{Pb}$ and $\mathrm{Cd}$ decays along $\mathrm{EO}$ treatment performed at the following conditions: volume of landfill leachate$0.3 \mathrm{~L}$; anode - BDD plate with $20 \mathrm{~cm}^{2}$; cathode — stainless steel plate

corresponds to a very toxic effluent and very close to be considered highly toxic (98.6 TU; see Fig. 4). After 4 h of EO treatment, the toxicity of the leachate increases, with an $\mathrm{EC}_{50}$ of $0.75 \%(133.0 \mathrm{TU})$, to start decreasing at the $8 \mathrm{~h}$ mark $\left(\mathrm{EC}_{50}=1.01 \%, 98.8 \mathrm{TU}\right)$ and continuing to decrease after $12 \mathrm{~h}\left(\mathrm{EC}_{50}=1.78 \%, 56.2 \mathrm{TU}\right)$. However, the 16-h assays register a new increase in toxicity $\left(\mathrm{EC}_{50}=0.65 \%\right.$, 153.1 TU). This increase is followed by a decrease until the 24-h treatment $\left(\mathrm{EC}_{50}=1.35 \%, 74.3 \mathrm{TU}\right.$, with a $20 \mathrm{~h}$ $\mathrm{EC}_{50}=0.91 \%, 109.5 \mathrm{TU}$ ) to be in turn followed by another increase at $28 \mathrm{~h}$, when the highest toxicity value was obtained $\left(\mathrm{EC}_{50}=0.53 \% ; 189.2 \mathrm{TU}\right.$, highly toxic effluent $)$. From then onwards, toxicity decreases to its lowest level at $36 \mathrm{~h}$ $\left(\mathrm{EC}_{50}=2.48 \%, 40.3 \mathrm{TU}\right)$. Such fluctuation in toxicity, particularly the increase after EO treatments, is well described in the literature. Wang et al. (2016) when testing the acute

Table 2 Evolution of D. magna acute toxicity across the different treatments. $\mathrm{EC}_{50}$ : concentration responsible for $50 \%$ of immobilization

\begin{tabular}{lll}
\hline Assay duration/h & $24 \mathrm{~h} \mathrm{EC}_{50}{ }^{\mathrm{a}}(\mathrm{TU})$ & $48 \mathrm{~h} \mathrm{EC}_{50}{ }^{\mathrm{a}}(\mathrm{TU})$ \\
\hline 0 (raw leachate) & $1.12(89.5)$ & $1.01(98.6)$ \\
4 & $0.95(105.1)$ & $0.75(133.0)$ \\
8 & $1.47(68.2)$ & $1.01(98.8)$ \\
12 & $1.99(50.3)$ & $1.78(56.2)$ \\
16 & $2.03(49.2)$ & $0.65(153.1)$ \\
20 & $1.48(67.4)$ & $0.91(109.5)$ \\
24 & $1.65(60.7)$ & $1.35(74.3)$ \\
28 & $0.93(107.6)$ & $0.53(189.2)$ \\
32 & $35.2(2.84)$ & $1.64(61.0)$ \\
36 & $47.6(2.10)$ & $2.48(40.3)$ \\
\hline
\end{tabular}

${ }^{\mathrm{a}} \mathrm{EC}_{50}$ expressed as dilution (\%)

$T U$ toxic units $\left(\mathrm{TU}=100 / \mathrm{EC}_{50}, 10<\mathrm{TU}<100\right.$ : very toxic (Pablos et al. 2011))

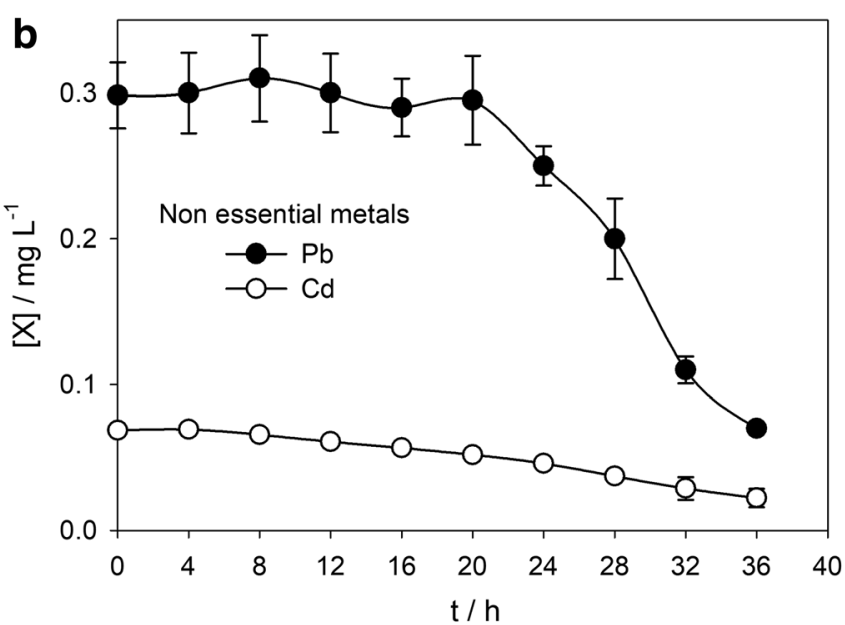

with $20 \mathrm{~cm}^{2}$; distance between electrodes $-0.5 \mathrm{~cm}$; applied current density $-700 \mathrm{~A} \mathrm{~m}^{-2}$; natural $\mathrm{pH}$

toxicity of a leachate towards D. magna, after Fenton treatment, obtained a significant increase in toxicity. The authors suggested that the toxicity of the intermediate products initially formed was probably greater than that of the primary pollutant. Gotsi et al. (2005) treated olive mill wastewaters with electrochemical oxidation methods and observed a sharp increase in the toxicity towards D. magna at short treatment times and even after prolonged oxidation, the toxicity levels remained high. In fact, in all experimental conditions, the toxicity of the treated effluent was higher than that of the original non-treated effluent. The authors quantified organochlorinated compounds by GC-MS and concluded that the formation of chlorinated compounds was responsible for the increased toxicity. Because they exhibit high octanol/water coefficient $\left(\mathrm{K}_{\mathrm{ow}}\right)$, they are able to interfere with biological membranes and thus exert toxic effects more pronounced towards living organisms. The formation

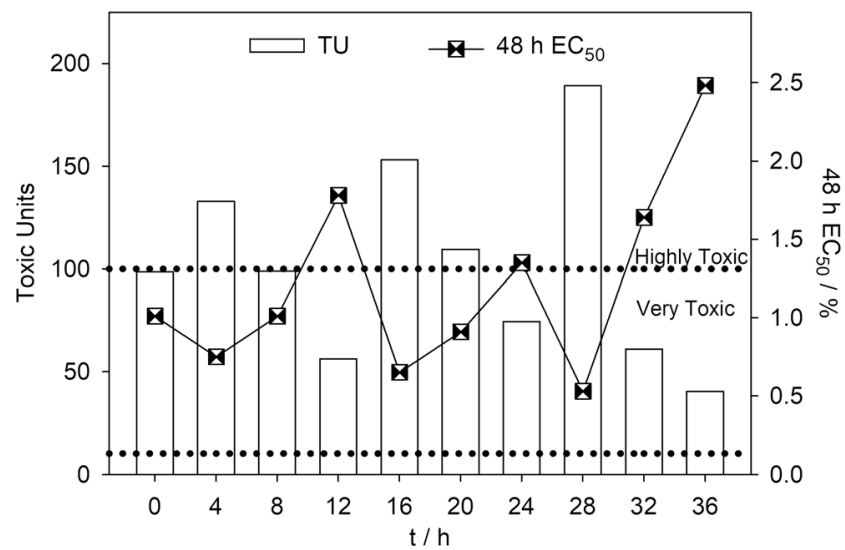

Fig. 4 Evolution of toxicity of the treated leachate towards D. magna in terms of $\mathrm{EC}_{50}$ (represented by black dots) and in terms of toxic units (represented by bars). The indication of the toxicity classification according to Pablos et al. (2011) is also depicted $(10<\mathrm{TU}<100$ : very toxic; $\mathrm{TU} \geq 100$ : highly toxic) 
Table 3 A summary of toxicity removal results previously reported for different treatments of sanitary landfill leachates

\begin{tabular}{|c|c|c|c|c|}
\hline Treatment process & Bioassay & $\begin{array}{l}\text { TU before } \\
\text { treatment }\end{array}$ & $\begin{array}{l}\text { Toxicity } \\
\text { reduction/TU } \\
(\%)\end{array}$ & Reference \\
\hline Electrochemical oxidation & Invertebrate (Daphnia magna) & 98.6 & $58.3(59)$ & This study \\
\hline Air stripping & $\begin{array}{l}\text { Invertebrate (Daphnia magna) } \\
\text { Algal assays (Raphidocelis subcapitata) }\end{array}$ & $\begin{array}{l}3.6 \\
50\end{array}$ & $\begin{array}{l}\text { a } \\
35.7(71)\end{array}$ & $\begin{array}{l}\text { Marttinen et al. } \\
2002\end{array}$ \\
\hline Nanofiltration & $\begin{array}{l}\text { Invertebrate (Daphnia magna) } \\
\text { Algal assays (Raphidocelis subcapitata) }\end{array}$ & $\begin{array}{l}6.3 \\
12.5\end{array}$ & $\begin{array}{l}2.5(40) \\
5.4(43)\end{array}$ & \\
\hline Ozonation & $\begin{array}{l}\text { Invertebrate (Daphnia magna) } \\
\text { Algal assays (Raphidocelis subcapitata) }\end{array}$ & $\begin{array}{l}4.8 \\
5.9\end{array}$ & $\begin{array}{l}\text { a } \\
\text { a }\end{array}$ & \\
\hline Coagulation/flocculation & $\begin{array}{l}\text { Luminescent bacteria (Vibrio fisheri) } \\
\text { Invertebrate (Daphnia similis) } \\
\text { Invertebrate (Artemia salina) } \\
\text { Fish (Brachydanio rerio) }\end{array}$ & $\begin{array}{l}6.7 \\
43.5 \\
8.4 \\
45.5\end{array}$ & $\begin{array}{l}\mathrm{a} \\
27.9(64) \\
2.7(32) \\
31.4(69)\end{array}$ & Silva et al. 2004 \\
\hline Ozonation (after coagulation/flocculation) & $\begin{array}{l}\text { Luminescent bacteria (Vibrio fisheri) } \\
\text { Invertebrate (Daphnia similis) } \\
\text { Invertebrate (Artemia salina) } \\
\text { Fish (Brachydanio rerio) }\end{array}$ & $\begin{array}{l}333 \\
15.6 \\
5.7 \\
14.1\end{array}$ & $\begin{array}{l}83(25) \\
\mathrm{a} \\
3.4(60) \\
7.8(55)\end{array}$ & \\
\hline Ultrafiltration & $\begin{array}{l}\text { Luminescent bacteria (Vibrio fisheri) } \\
\text { Invertebrate (Daphnia similis) } \\
\text { Invertebrate (Artemia salina) }\end{array}$ & $\begin{array}{l}6.7 \\
43.5 \\
8.4\end{array}$ & $\begin{array}{l}0.2(3) \\
29.2(67) \\
5.8(69)\end{array}$ & \\
\hline Coagulation/flocculation + air striping & $\begin{array}{l}\text { Luminescent bacteria (Vibrio fisheri) } \\
\text { Invertebrate (Daphnia similis) }\end{array}$ & $\begin{array}{l}6.7 \\
43.5\end{array}$ & $\begin{array}{l}3.3(49) \\
36.4(84)\end{array}$ & \\
\hline Coagulation/flocculation + Ozonation & $\begin{array}{l}\text { Fish (Brachydanio rerio) } \\
\text { Fish (Poecilia vivípara) }\end{array}$ & $\begin{array}{l}16.1 \\
44.6\end{array}$ & $\begin{array}{l}7.8(48) \\
37.7(85)\end{array}$ & Bila et al. 2005 \\
\hline Electrochemical oxidation & Luminescent bacteria (Vibrio fischeri) & 5.6 & $3.3(59)$ & $\begin{array}{l}\text { Anglada et al. } \\
2011\end{array}$ \\
\hline Coagulation & $\begin{array}{l}\text { Fish (Oreochromis niloticus) } \\
\text { Fish (Cyprinus carpio) } \\
\text { Invertebrate (Moina macrocopa) }\end{array}$ & $\begin{array}{l}23.7 \\
12.8 \\
12.4\end{array}$ & $\begin{array}{l}19.1(81) \\
7.4(58) \\
6.7(54)\end{array}$ & $\begin{array}{l}\text { Theepharaksapan } \\
\text { et al. } 2011\end{array}$ \\
\hline Sand filtration (after coagulation) & $\begin{array}{l}\text { Fish (Oreochromis niloticus) } \\
\text { Fish (Cyprinus carpio) } \\
\text { Invertebrate (Moina macrocopa) }\end{array}$ & $\begin{array}{l}4.6 \\
5.4 \\
5.7\end{array}$ & $\begin{array}{l}1.1(24) \\
1.6(30) \\
1.5(26)\end{array}$ & \\
\hline Microfiltration (after coagulation + sand filtration) & $\begin{array}{l}\text { Fish (Oreochromis niloticus) } \\
\text { Fish (Cyprinus carpio) } \\
\text { Invertebrate (Moina macrocopa) }\end{array}$ & $\begin{array}{l}3.5 \\
3.8 \\
4.2\end{array}$ & $\begin{array}{l}0.9(26) \\
0.4(11) \\
1.3(31)\end{array}$ & \\
\hline $\begin{array}{l}\text { Reverse osmosis (after coagulation }+ \text { sand } \\
\text { filtration }+ \text { microfiltration) }\end{array}$ & $\begin{array}{l}\text { Fish (Oreochromis niloticus) } \\
\text { Fish (Cyprinus carpio) } \\
\text { Invertebrate (Moina macrocopa) }\end{array}$ & $\begin{array}{l}2.6 \\
3.4 \\
2.9\end{array}$ & $\begin{array}{l}2.6(100) \\
3.4(100) \\
2.9(100)\end{array}$ & \\
\hline Fenton & $\begin{array}{l}\text { Luminescent bacteria (Photobacterium } \\
\text { phosphoreum T3 mutation) }\end{array}$ & $236.3^{\mathrm{b}}$ & $\mathrm{b}$ & He et al. 2015 \\
\hline $\begin{array}{l}\text { Electrochemical oxidation } \\
\text { Biological reactor }\end{array}$ & Luminescent bacteria (Vibrio fischeri) & 16.7 & $12.2(73)$ & $\begin{array}{l}\text { Del Moro et al. } \\
2016\end{array}$ \\
\hline Biological reactor + electrochemical oxidation & & & $15.0(90)$ & \\
\hline Coagulation/sedimentation & $\begin{array}{l}\text { Luminescent bacteria (Vibrio fischeri) } \\
\text { Fish (Zebrafish larvae) } \\
\text { Fish (Zebrafish embryos) }\end{array}$ & $\begin{array}{l}3.4 \\
84.8 \\
82.6\end{array}$ & $\begin{array}{l}1.8(53) \\
28.9(34) \\
55.6(67)\end{array}$ & Qiu et al. 2016 \\
\hline Anaerobic reactor (after coagulation/sedimentation) & $\begin{array}{l}\text { Luminescent bacteria (Vibrio fischeri) } \\
\text { Fish (Zebrafish larvae) } \\
\text { Fish (Zebrafish embryos) }\end{array}$ & $\begin{array}{l}1.6 \\
55.9 \\
27.0\end{array}$ & $\begin{array}{l}0.3(19) \\
20.7(37) \\
8.1(30)\end{array}$ & \\
\hline $\begin{array}{l}\text { Electrochemical oxidation (after } \\
\text { coagulation/sedimentation + anaerobic reactor) }\end{array}$ & $\begin{array}{l}\text { Luminescent bacteria (Vibrio fischeri) } \\
\text { Fish (Zebrafish larvae) }\end{array}$ & $\begin{array}{l}1.3 \\
35.2\end{array}$ & $\begin{array}{l}0.7(31) \\
14.9(42)\end{array}$ & \\
\hline
\end{tabular}


Table 3 (continued)

\begin{tabular}{|c|c|c|c|c|}
\hline Treatment process & Bioassay & $\begin{array}{l}\text { TU before } \\
\text { treatment }\end{array}$ & $\begin{array}{l}\text { Toxicity } \\
\text { reduction/TU } \\
(\%)\end{array}$ & Reference \\
\hline \multirow{4}{*}{$\begin{array}{l}\text { Aerobic reactor (after } \\
\text { coagulation/sedimentation + anaerobic } \\
\text { reactor + electrochemical oxidation) }\end{array}$} & Fish (Zebrafish embryos) & 18.9 & $5.9(31)$ & \multirow{9}{*}{$\begin{array}{l}\text { Zolfaghari et al. } \\
\quad 2016\end{array}$} \\
\hline & Luminescent bacteria (Vibrio fischeri) & 0.9 & $0.3(33)$ & \\
\hline & Fish (Zebrafish larvae) & 20.3 & $8.3(41)$ & \\
\hline & Fish (Zebrafish embryos) & 13.0 & $2.4(18)$ & \\
\hline Membrane bioreactor & $\begin{array}{l}\text { Luminescent bacteria (Vibrio fischeri) } \\
\text { Invertebrate (Daphnia magna) }\end{array}$ & $\begin{array}{l}53 \\
15\end{array}$ & $\begin{array}{l}50.2(95) \\
13.8(92)\end{array}$ & \\
\hline Electrochemical oxidation (after membrane bioreactor) & Invertebrate (Daphnia magna) & 1.2 & a & \\
\hline \multirow[t]{2}{*}{ Electrochemical oxidation } & Luminescent bacteria (Vibrio fischeri) & 53 & $26(49)$ & \\
\hline & Invertebrate (Daphnia magna) & 15 & a & \\
\hline \multirow[t]{2}{*}{ Membrane bioreactor (after electrochemical oxidation) } & Luminescent bacteria (Vibrio fischeri) & 27 & $25.5(94)$ & \\
\hline & Invertebrate (Daphnia magna) & 17 & $14.3(84)$ & \\
\hline $\begin{array}{l}\text { Dark Fenton } \\
\text { Solar photo-Fenton }\end{array}$ & $\begin{array}{l}\text { Luminescent bacteria (Aliivibrio } \\
\text { fischeri) }\end{array}$ & 7.7 & $\begin{array}{l}5.8(75) \\
6.0(78)\end{array}$ & Costa et al. 2018 \\
\hline
\end{tabular}

$T U$ toxic units ( $\mathrm{TU}=100 /\left(\% \mathrm{EC}_{50}\right.$ or $\left.\left.\% \mathrm{LC}_{50}\right)\right)($ Ghosh et al. 2017$)$

${ }^{a}$ An increase in toxicity was observed after treatment

${ }^{\mathrm{b}} \mathrm{EC}_{50}$ value in $\mathrm{mg} \mathrm{L}^{-1} . \mathrm{EC}_{50}$ after treatment $=225.6 \mathrm{mg} \mathrm{L}^{-1}$

of organochlorinated compounds during electrochemical treatment was also considered to be the cause for the higher toxicities obtained by Costa et al. (2008) when treating tannery wastewater with a current density of $100 \mathrm{~mA} \mathrm{~cm}^{-2}$. It is thus possible that, in the present study, these compounds will also be responsible for the increased toxicity observed at specific time points of EO treatment. Since neither chlorate nor perchlorate had statistically significant different correlations with $\mathrm{EC}_{50}$ (Pearson productmoment correlation, $p=0.440$, and Spearman rank correlation, $p=0.7982$, respectively), it can be postulated that toxicity was modulated (as previously mentioned) by organochlorinated compounds. Reinforcing this hypothesis is the fact that the other causes of toxicity generally identified, namely ammonia, metals, and alkalinity (Thomas et al. 2009), also did not show statistically significant correlations with the $\mathrm{EC}_{50}$ obtained for the treatments. Pearson productmoment correlation was used to test the linear association between $\mathrm{EC}_{50}$ and ammonia, and the metals $\mathrm{Ni}, \mathrm{Zn}$, and $\mathrm{Cd}$ returning $p$ values above the 5\% significance level ( $p=$ $0.2964,0.2403,0.3724$, and 0.1011 , respectively). Nonnormally distributed variables $\mathrm{Pb}$ and $\mathrm{pH}$ were tested using Spearman rank correlation, being the obtained $p$ values 0.5587 and 0.4589 , respectively. COD is a legal criterion for direct leachate discharge and $\mathrm{BOD}_{5} / \mathrm{COD}$ is a wellaccepted stability index. However, by not obtaining statistically significant correlations between $\mathrm{EC}_{50}$ and $\mathrm{COD}$ and $\mathrm{BOD}_{5} / \mathrm{COD}$ (Pearson product-moment correlation, $p=$ 0.3130 and 0.0910 , respectively), the results also reinforce that the use of those parameters without the aid of bioassays is not suitable for evaluating toxicity of effluents towards aquatic organisms.

As above-mentioned, there was an overall decrease in toxicity at the end of the treatment. After $36 \mathrm{~h}$ of oxidation, the lowest toxicity was registered, corresponding to a $59 \%$ decrease in toxicity. This is further indication that chloramines were, potentially, the main responsible for the registered toxicity. In fact, they fit the profile of varying toxicity, by being formed during the process as by-products, but being transformed into other compounds, this transformation being total at the end of the experiment (36-h treatment) without any chloramines present in solution, since all existent nitrogen was in the form of nitrate. Anglada et al. (2011) that assessed the acute ecotoxicity of a landfill leachate treated by EO with a BDD anode, using the luminescent marine bacteria Vibrio fischeri, obtained similar overall results, although the initial toxicity of the effluent was significantly lower $(\mathrm{TU}=5.6)$ than the one utilized in the present study ( $T U=98.6)$. They found that the toxicity of the raw sample yielded $\mathrm{EC}_{50}$ values of $18 \%$ whereas after $8 \mathrm{~h}$ of treatment, the $\mathrm{EC}_{50}$ increased to $43 \%$, concluding that $\mathrm{EO}$ process decreased the toxicity, even though chlorinated volatile organic compounds were formed (Anglada et al. 2011). When the results obtained in the present work are compared with others described in the literature for different leachate treatments, summarized in Table 3, it can be seen that few treatment processes achieved the absolute toxicity reduction accomplished by the present work, which shows one of the highest toxicities towards D. magna for the initial sample. This indicates that electrochemical oxidation is feasible for reducing the acute toxicity of sanitary landfill leachates. 
In data presented in Table 3, different test organisms were used, which makes a direct comparison unfeasible. It is also important to emphasize that in some of these studies, toxicity evaluation was performed only by bioassays with luminescent bacteria. Though this type of bioassays responds to the presence of organic compounds and ammonia, it shows reduced sensitivity to inorganic compounds, being this a major limitation to its application in leachate toxicity evaluation (Ghosh et al. 2017). Coagulation, membrane bioreactors, and reverse osmosis are among the treatment processes that lead to toxicity reductions above $60 \%$. However, this kind of technology presents the disadvantage of sludge/concentrates production, not offering a treatment solution, but a problem transfer.

\section{Conclusions}

The electrochemical oxidation treatment effectively removed the organic load and ammonium nitrogen present in the sanitary landfill leachate and reduced the heavy metal ions, including the toxic $\mathrm{Cd}$ and $\mathrm{Pb}$. Furthermore, the toxicity of the sanitary landfill leachate was significantly reduced, with a decrease in the acute toxicity towards $D$. magna of 59\%. Despite such a significant reduction in acute toxicity, the treated leachate was still very toxic, and therefore, further treatments are necessary to remove completely the toxicity of the effluent.

After $36 \mathrm{~h}$ of treatment, COD was below the legal Portuguese discharge limit $\left(150 \mathrm{mg} \mathrm{L}^{-1}\right)$ and the biodegradability index $\left(\mathrm{BOD}_{5} / \mathrm{COD}\right)$ was 0.84 . These parameters are, respectively, legal criteria for direct leachate discharge and an accepted stability index. However, their correlations with $\mathrm{EC}_{50}$ were not statistically significant and the results emphasize that the use of those parameters without the aid of bioassays is not suitable for evaluating toxicity of effluents towards aquatic organisms.

The toxicity results obtained in this work were compared with results from other SLL degradation studies, performed using different technologies. Although different test organisms were utilized in the toxicological evaluation, the following conclusions can be drawn: electrochemical oxidation is effective in the reduction of acute toxicity, even when the initial toxicity is as high as the observed for the SLL studied in this work; in several studies, bioassays were performed with luminescent bacteria, which respond to the presence of organic compounds and ammonia, but shows reduced sensitivity to inorganic compounds, being inadequate to evaluate toxicity in SLL; although coagulation, membrane bioreactors, and reverse osmosis lead, in general, to toxicity reductions in the treated effluent higher than $60 \%$, the toxic pollutants stay in the sludge/concentrates produced.
Acknowledgments The authors wish to thank Professor Amadeu M.V.M. Soares for providing the initial culture of D. magna.

Funding The authors gratefully acknowledge the financial support from Fundação para a Ciência e a Tecnologia, FCT, to the projects UID/Multi/ 00195/2013, UID/Multi/00709/2013, SFRH/BPD/103615/2014 (A. Fernandes), SFRH/BD/109901/2015 (A.S. Rodrigues), and SFRH/BD/ 132436/2017 (M.J. Nunes). Additional financial support was provided by FEDER funds through the POCI-COMPETE 2020-Operational Programme Competitiveness and Internationalisation in Axis IStrengthening research, technological development and innovation (Project POCI-01-0145-FEDER-007491), and from Santander Totta Universidades, project BID/ICI-UID FC/Santander Totta Universidades-UBI/2016 (R. Silva). A.C.A. Sousa also acknowledges the financial support of CNRS LabEx DRIIHM.

\section{References}

Anglada A, Urtiaga A, Ortiz I (2009) Contributions of electrochemical oxidation to waste-water treatment: fundamentals and review of applications. J Chem Technol Biotechnol 84:1747-1755. https://doi. org/10.1002/jctb. 2214

Anglada A, Urtiaga A, Ortiz I (2010) Laboratory and pilot plant scale study on the electrochemical oxidation of landfill leachate. J Hazard Mater 181:729-735. https://doi.org/10.1016/j.jhazmat.2010.05.073

Anglada A, Urtiaga A, Ortiz I, Mantzavinos D, Diamadopoulos E (2011) Boron doped diamond anodic treatment of landfill leachate: evaluation of operating variables and formation of oxidation by-products. Water Res 45:828-838. https://doi.org/ 10.1016/j.watres.2010.09.017

Bila DM, Montalvão AF, Silva AC, Dezotti M (2005) Ozonation of a landfill leachate: evaluation of toxicity removal and biodegradability improvement. J Hazard Mater B 117:235-242. https://doi.org/10. 1016/j.jhazmat.2004.09.022

Brillas E, Martínez-Huitle CA (2015) Decontamination of wastewaters containing synthetic organic dyes by electrochemical methods. An updated review. Appl Catal B Environ 166-167:603-643. https:// doi.org/10.1016/j.apcatb.2014.11.016

Costa CR, Botta CMR, Espindola ELG, Olivi P (2008) Electrochemical treatment of tannery wastewater using DSA $®$ electrodes. J Hazard Mater 153:616-627. https://doi.org/10.1016/j.jhazmat.2007.09.005

Costa FM, Daflon SDA, Bila DM, Fonseca FV, Campos JC (2018) Evaluation of the biodegradability and toxicity of landfill leachates after pretreatment using advanced oxidative processes. Waste Manag 76:606-613. https://doi.org/10.1016/j.wasman.2018.02.030

Del Moro G, Prieto-Rodríguez L, De Sanctis M, Di Iaconi C, Malato S, Mascolo G (2016) Landfill leachate treatment: comparison of standalone electrochemical degradation and combined with a novel biofilter. Chem Eng J 288:87-98. https:// doi.org/10.1016/j.cej.2015.11.069

Eaton A, Clesceri L, Rice E, Greenberg A, Franson MA (2005) Standard methods for examination of water and wastewater, $21 \mathrm{st}$ edn. American Public Health Association, Washington DC

Eggen T, Moeder M, Arukwe A (2010) Municipal landfill leachates: a significant source for new and emerging pollutants. Sci Total Environ 408:5147-5157. https://doi.org/10.1016/j.scitotenv. 2010.07.049

Fernandes A, Pacheco MJ, Ciríaco L, Lopes A (2012) Anodic oxidation of a biologically treated leachate on a boron-doped diamond anode. J Hazard Mater 199-200:82-87. https://doi.org/10.1016/j.jhazmat. 2011.10.074

Fernandes A, Spranger P, Fonseca AD, Pacheco MJ, Ciríaco L, Lopes A (2014) Effect of electrochemical treatments on the biodegradability 
of sanitary landfill leachates. Appl Catal B Environ 144:514-520. https://doi.org/10.1016/j.apcatb.2013.07.054

Fernandes A, Pacheco MJ, Ciríaco L, Lopes A (2015) Review on the electrochemical processes for the treatment of sanitary landfill leachates: present and future. Appl Catal B Environ 176:183-200. https:// doi.org/10.1016/j.apcatb.2015.03.052

Freire DDC, Sant'Anna GL (1998) A proposed method modification for the determination of COD in Salina waters. Environ Technol 19: 1243-1247. https://doi.org/10.1080/09593331908616784

Ghosh P, Thakur IS, Kaushik A (2017) Bioassays for toxicological risk assessment of landfill leachate: a review. Ecotoxicol Environ Saf 141:259-270. https://doi.org/10.1016/j.ecoenv.2017.03.023

Gotsi M, Kalogerakis N, Psillakis E, Samaras P, Mantzavinos D (2005) Electrochemical oxidation of olive oil mill wastewaters. Water Res 39:4177-4187. https://doi.org/10.1016/j.ecoenv.2017.03.023

He R, Tian B-H, Zhang Q-Q, Zhang H-T (2015) Effect of Fenton oxidation on biodegradability, biotoxicity and dissolved organic matter distribution of concentrated landfill leachate derived from a membrane process. Waste Manag 38:232-239. https://doi.org/10.1016/j. wasman.2015.01.006

Ma M, Li J, Wang Z (2005) Assessing the detoxication efficiencies of waste water treatment processes using a battery of bioassays/biomarkers. Arch Environ Contam Toxicol 49:480-487. https://doi. org/10.1007/s00244-004-0204-Z

Martínez-Huitle CA, Ferro S (2006) Electrochemical oxidation of organic pollutants for the wastewater treatment: direct and indirect processes. Chem Soc Rev 35:1324-1340. https://doi.org/10.1039/ b517632h

Martínez-Huitle CA, Rodrigo MA, Sirés I, Scialdone O (2015) Single and coupled electrochemical processes and reactors for the abatement of organic water pollutants: a critical review. Chem Rev 115:1336213407. https://doi.org/10.1021/acs.chemrev.5b00361

Marttinen SK, Kettunen RH, Sormunen KM, Soimasuo RM, Rintala JA (2002) Screening of physical-chemical methods for removal of organic material, nitrogen and toxicity from low strength landfill leachates. Chemosphere 46:851-858. https://doi.org/10.1016/ S0045-6535(01)00150-3

OECD/OCDE (2004). OECD guideline for testing of chemicals Daphnia so., acute immobilisation test. OECD

Öman CB, Junestedt C (2008) Chemical characterization of landfill leachates -400 parameters and compounds. Waste Manag 28: 1876-1891. https://doi.org/10.1016/j.wasman.2007.06.018

Pablos MV, Martini F, Fernández C, Babín MM, Herraez I, Miranda J, Martínez J, Carbonell G, San-Segundo L, García-Hortigüela P, Tarazona JV (2011) Correlation between physicochemical and ecotoxicological approaches to estimate landfill leachates toxicity. Waste Manag 31:1841-1847. https://doi.org/10.1016/j. wasman.2011.03.022
Panizza M, Cerisola G (2009) Direct and mediated anodic oxidation of organic pollutants. Chem Rev 109:6541-6569. https://doi.org/10. $1021 /$ cr9001319

Panizza M, Martinez-Huitle CA (2013) Role of electrode materials for the anodic oxidation of a real landfill leachate - comparison between Ti-Ru-Sn ternary oxide, $\mathrm{PbO}_{2}$ and boron-doped diamond anode. Chemosphere 90:1455-1460. https://doi.org/10.1016/j. chemosphere.2012.09.006

Pérez G, Saiz J, Ibañez R, Urtiaga A, Ortiz I (2012) Assessment of the formation of inorganic oxidation by-products during the electrocatalytic treatment of ammonium from landfill leachates. Water Res 46: 2579-2590. https://doi.org/10.1016/j.watres.2012.02.015

Qiu A, Cai Q, Zhao Y, Guo Y, Zhao L (2016) Evaluation of the treatment process of landfill leachate using the toxicity assessment method. Int J Environ Res Public Health 13:1262. https://doi.org/10.3390/ ijerph13121262

Rao ANS, Venkatarangaiah VT (2014) Metal oxide-coated anodes in wastewater treatment. Environ Sci Pollut Res 21:3197-3217. https://doi.org/10.1007/s11356-013-2313-6

Sabejeje AJ, Oketayo OO, Bello IJ, Sabejeje TA (2014) Elemental analysis of leachates from open-dump-solid wastes in Ondo state, Nigeria: implication on underground water and surface water safety. Am J Res Commun 2:287-296

Silva AC, Dezotti M, Sant'Anna GL Jr (2004) Treatment and detoxification of a sanitary landfill leachate. Chemosphere 55:207-214. https://doi.org/10.1016/j.chemosphere.2003.10.013

Sirés I, Brillas E, Oturan MA, Rodrigo MA, Panizza M (2014) Electrochemical advanced oxidation processes: today and tomorrow. A review. Environ Sci Pollut Res 21:8336-8367. https://doi. org/10.1007/s11356-014-2783-1

Theepharaksapan S, Chiemchaisri C, Chiemchaisri W, Yamamoto K (2011) Removal of pollutants and reduction of bio-toxicity in a full scale chemical coagulation and reverse osmosis leachate treatment system. Bioresour Technol 102:5381-5388. https://doi.org/10.1016/ j.biortech.2010.11.091

Thomas DJL, Tyrrel SF, Smith R, Farrow S (2009) Bioassays for the evaluation of landfill leachate toxicity. J Toxicol Env Health B 12: 83-105. https://doi.org/10.1080/10937400802545292

Wang G, Lu G, Zhao J, Yin P, Zhao L (2016) Evaluation of toxicity and estrogenicity of the landfill-concentrated leachate during advanced oxidation treatment: chemical analyses and bioanalytical tools. Environ Sci Pollut Res 23:16015-16024. https://doi.org/10.1007/ s11356-016-6669-2

Zolfaghari M, Jardak K, Drogui P, Brar SK, Buelna G, Dubé R (2016) Landfill leachate treatment by sequential membrane bioreactor and electro-oxidation processes. J Environ Manag 184:318-326. https:// doi.org/10.1016/j.jenvman.2016.10.010 